\section{The FPM International Awards for Medical Writing in Social Media: a step in the right direction}

We read the editorial by Singer and colleagues with great interest. ${ }^{1}$ It is encouraging to see the medical community mobilising in this way in response to the threat of medical misinformation. This announcement is timely; as the coronavirus disease (COVID-19) pandemic escalates, we see more and more medical misinformation being circulated online, from conspiracy theories regarding the origins of the virus to non-evidence based home remedies. ${ }^{2}$ This needs to be addressed by key stakeholders, including healthcare professionals. The collaboration between the Fellowship of Postgraduate Medicine (FPM) and its journals to launch international awards for 'well-informed, clear writing on health matters in social media' may encourage more clinicians to engage in health science communication on social media.

In a recent editorial in this journal, ${ }^{3} \mathrm{I}$ argued that doctors should act as advocates in the fight against medical misinformation on the social media, even if this is only in the context of their own social network. Healthcare professionals may understandably have reservations about engaging with social media platforms in a professional context, due to fears associated with the mixing of their personal and professional lives. However, major professional bodies including the General Medical Council, the British Medical Association, the Royal College of General Practitioners and the Nursing and Midwifery Council have all published specific guidance on the use of social media to help inform healthcare professionals regarding best practice. ${ }^{4-7}$

Why exactly should healthcare professionals disseminate health-related information online? In the most recent Ipsos MORI 'Trust in professions' survey, 'Nurses' and 'Doctors' remained the two most trusted professions in the UK, with $95 \%$ and $93 \%$ of survey respondents (1020 British adults aged $\geq 15$ ) stating that they would trust these professionals to tell the truth, respectively. ${ }^{8}$ These trust ratings contrast significantly with those given to professionals in the categories 'Politicians generally' (14\%) and 'Journalists' (26\%). The significance of these findings is that as healthcare professionals we can leverage this trust and use our expertise to better educate patients on social media. Moreover, current evidence suggests that individuals can reduce health misperceptions on social media by directly refuting false or misleading claims, provided that these refutations are 'performed clearly, simply, and with evidence, and providing them appropriate sources to accompany their refutation'.9

We applaud the FPM and its journals for encouraging writing in social media and for supporting clinicians to do so. Medical journals could also commission or invite submissions pertaining to the topic of medical misinformation, to help drive forward research in this area. ${ }^{10}$ For example, the American Journal of Public Health recently invited submissions for their 'Special Issue about Health Misinformation on Social Media' which is due for publication later this year. ${ }^{11}$ The FPM International Awards for Medical Writing in Social Media is a step in the right direction. More research is urgently needed to inform clinicians, scientists and public health professionals regarding how best to engage with the general public on social media and how to combat medical misinformation online.

\section{Samuel P Trethewey $\odot{ }^{1}$ Kathryn J Beck, ${ }^{1}$ Rehan F Symonds ${ }^{1,2}$}

${ }^{1}$ Oak Tree Surgery, Liskeard, Cornwall, UK ${ }^{2}$ Cornwall Clinical Research Group, Cornwall, UK

Correspondence to Dr Samuel P Trethewey, Oak Tree Surgery, Liskeard, Cornwall, UK; s-trethewey@doctors.org.uk

Contributors SPT drafted the manuscript and this was edited by KJB and RFS. All authors have read and approved the final version for submission.

Funding The authors have not declared a specific grant for this research from any funding agency in the public, commercial or not-for-profit sectors.

Competing interests None declared.

Patient consent for publication Not required.

Provenance and peer review Not commissioned; internally peer reviewed.
This article is made freely available for use in accordance with BMJ's website terms and conditions for the duration of the covid-19 pandemic or until otherwise determined by BMJ. You may use, download and print the article for any lawful, non-commercial purpose (including text and data mining) provided that all copyright notices and trade marks are retained.

(C) Author(s) (or their employer(s)) 2020. No commercial re-use. See rights and permissions. Published by BMJ.

\section{Check for updates}

To cite Trethewey SP, Beck KJ, Symonds RF. Postgrad Med J 2020;96:304.

Accepted 28 March 2020

Published Online First 2 April 2020

Postgrad Med J 2020;96:304.

doi:10.1136/postgradmedj-2020-137772

\section{ORCID iD}

Samuel P Trethewey http://orcid.org/0000-0003-01502283

\section{REFERENCES}

1 Singer D, Redekop K, Cheung B. Trusted writing in social media: FPM international awards for medical writing in social media. Postgrad Med J 2020;96:183.

2 Mian A, Khan S. Coronavirus: the spread of misinformation. BMC Med 2020;18:89

3 Trethewey SP. Strategies to combat medical misinformation on social media. Postgrad Med J 2020;96:4-6.

4 General Medical Council. Doctors' use of social Media. London, 2013. Available: https://www.gmc-uk.org/ ethical-guidance/ethical-guidance-for-doctors/doctorsuse-of-social-media/doctors-use-of-social-media [Accessed 25 Mar 2020].

5 British Medical Association. Social media guidance for doctors, 2019. Available: https://www.bma.org.uk/ advice/employment/ethics/social-media-guidance-fordoctors [Accessed 25th March 2020].

6 Royal College of General Practitioners. Social media highway code, 2013. Available: https://www.rcgp.org. uk/social-media [Accessed 25 Mar 2020].

7 Nursing and Midwifery Council. Social media guidance. Available: https://www.nmc.org.uk/standards/ guidance/social-media-guidance/ [Accessed $25 \mathrm{Mar}$ 2020].

8 Ipsos MORI. Ipsos MORI Veracity Index - Trust in Professions, 2019. Available: https://www.ipsos. com/sites/default/files/ct/news/documents/2019-11/ trust-in-professions-veracity-index-2019-slides.pdf [Accessed 25 Mar 2020].

9 Bode L, Vraga EK, Something S. See something, say something: correction of global health misinformation on social media. Health Commun 2018;33:1131-40.

10 Armstrong PW, Naylor CD. Counteracting health misinformation: a role for medical journals? JAMA 2019;321:1863-4.

11 American Public Health Association. Call for proposals: special issue about health misinformation on social media. Available: https://ajph.aphapublications.org/ pb-assets/downloads/CFP_HealthMisinformation_Full. pdf [Accessed 25 Mar 2020]. 